\title{
GENETIC PARAMETERS OF SOME SORGHUM (SORGHUM BICOLOR (L.) MOENCH) GENOTYPES UNDER WATER DEFICIT STRESS
}

\author{
Badran, Ayman E. \\ Department of Genetic Resources, Desert Research Center, El- \\ Matareya, Cairo, Egypt. \\ E-mail: dr.ayman_badran@yahoo.com
}

\begin{abstract}
$\mathrm{S}$
orghum (Sorghum bicolor (L.) Moench) has a mighty adaptation possibility, which are important parameters of genotypes growing in severe conditions. This study focused on the differential responses of six genotypes under two levels of water deficit (20 and $40 \%$ decrease in water rate) compared with normal conditions during two seasons. Variance components and tolerance indices under different environments provide new chances for breeders to select genotypes, which have high yielding and are stress tolerant. The results showed the superiority in the performance of Shandawil variety under normal conditions, while Line 3 showed a marked superiority under high drought stress compared to other genotypes. The results of the variance components of most studied traits showed that the major contribution in phenotypic performance is due to the genetic variation. According to heritability in broad sense, the values ranged from 27.82 to $99.12 \%$. With regard to the genetic advances, the results showed a clear discrepancy among the studied traits, as the characteristics of the plant height, fresh weight and grain yield of the plant recorded the highest genetic advance, while chlorophyll content recorded the lowest genetic advance of the plants.
\end{abstract}

Keywords: variance components, phenotypic, heritability, genetic advances

\section{INTRODUCTION}

Sorghum (Sorghum bicolor (L.) Moench) belongs to the C4 cereal crops that were originated in Africa. The sorghum is the fifth major cereal crop in the world and is one of the most important crops grown in very diverse environments of deficit water stress, soil fertility and temperature conditions 
(Mindaye et al., 2016). The production of sorghum does not meet the increasing demand of most of the of developing countries population in Africa due to the low cereal yield, about 0.28 tons/hectare, compared to some countries such as the United States of America (4.30 tons/hectare) and Argentina (4.90 tons/hectare), according to the World Food Organization report (FAOSTAT, 2013). The decrease in production is due to biotic and abiotic stresses, especially drought reactions in sorghum entries can be of physiological, morphological and phonological kind (Verma et al., 2018). As well as the use of domestic genotypes with low production capacity (limited genetic potential) where farmers mostly rely on local species with low yields, so sorghum production fails to meet the demand for an increase in the population in those countries (Maman et al., 2004). Accordingly, plant breeders were required to supply farmers with improved sorghum genotypes. So, the identification of the superior genotypes with the desired traits and their subsequent use in breeding program using appropriate selection criteria can be beneficial to successful improvement programs especially under environmental stress conditions. Therefore, selection criteria for suitable genotype may depend on one or more of the characteristics of the crop, which requires basic information on the nature and extent of variation in the available genotypes, and the degree of environmental effect on the performance of these characters contributing in the yield. Phenotypic variance includes genotypic variance, environmental variance and the interactions of genotype $\mathrm{x}$ environment. So, variance evaluating of yield and its components could be a key to the success in the planning of sorghum improvement program. Comparative variability of traits is evaluated by estimating the genotypic and the phenotypic coefficient of variation and interaction between them (Ahmad et al., 2011). In the same manner, heritability is defined in a broad sense as the ratio between genetic variation to total phenotypic variation, while is defined in the narrow sense as the ratio of the additional component of genetic variation to complete phenotype variation which is more sensitive and accurate, but it is more difficult to estimate. In general, these heritability estimates are useful for calculating the expected genetic advancing as a result of the selection of the traits (Bello et al., 2007; Sami et al., 2013 and Badran and Moustafa, 2015). On the other hand, drought indices used as a mathematical relation based on loss of yield under drought stress conditions as comparison with normal conditions, which have been used for screening drought resistance genotypes (Fernandez, 1992; Mitra 2001; Sio-Se Mardeh et al., 2006 and Shirani Rad and Abbasian, 2011). The biplot graphical show of the data is a beneficial manner that graphically offer the two-way (genotype $\mathrm{x}$ environment) data and allows conception of the interaction among genotypes and environments, and interactions (Yan and Kang, 2003). So, Plant breeders has found GGE biplot analysis to be beneficial for genotype evaluation.

Egyptian J. Desert Res., 70, No. 2, 103-119 (2020) 
This study focuses on the study of the components of variance and heritability coefficient in broad sense, the genetic advancing of tested traits as well as the evaluation of the genetic behavior of tested sorghum genotypes under normal and drought stress conditions, based on tolerance indices.

\section{Experimental Conditions}

\section{MATERIALS AND METHODS}

A field experiment was carried out at Beni Suef governorate, Egypt during the two growing seasons; 2017 and 2018. The seeds of three commercial cultivars (Dorado, Shandawil and Hybrid 306) obtained from the Agriculture Research Center (ARC), Egypt and three lines [Line 1 (ICSV 93046), Line 2 (ICSR 930 34) and Line 3 (SP 4487-3)] obtained from International Center for Bio-saline agriculture (ICBA), United Arab Emirates were evaluated. The tested genotypes have been evaluated under three irrigation levels i.e., normal irrigation (T1), which were added according to Khurmi (1984), while deficit water stress treatments were imposed after two weeks from planting by reducing available water supply by rate of $20 \%$ (T2) and $40 \%$ (T3), compared with the normal irrigation level $(7 \mathrm{~mm} / \mathrm{fed} / \mathrm{day})$ through gated pipe irrigation system, which were equivalent to 7056 $\mathrm{m}^{3} /$ hectare. The seeds of tested genotypes were planted in a sandy soil, $\mathrm{pH}=$ 7.98 and $\mathrm{EC}=4.1 \mathrm{dSm}^{-1}$. On the other hand, the recommended cultural practices were carried out during the two growing seasons.

With regard to meteorology, it was recorded as an average for 2107 and 2108 seasons during the period from April to August, as the following:

- Night temperature $\left({ }^{\circ} \mathrm{C}\right.$ ): ranged from 13.8 (during April) to $21.6^{\circ} \mathrm{C}$ (during July).

- Day temperature $\left({ }^{\circ} \mathrm{C}\right.$ ): ranged from 30.3 (during April) to $37.1^{\circ} \mathrm{C}$ (during July).

- Rainfall rate (\%): $0.0 \%$ during the months of agriculture.

- Humidity (\%): ranged from 35 (during July) to 50\% (during August).

- Daylight hours (h): ranged from 12 (during April) to 14 hours (during June).

2. Data Collection and Recorded as Follow:

Data were collected and recorded as follows:

(a) Measurements after 50 days from planting: fresh weight/plant $(\mathrm{g})$, dry weight/plant $(\mathrm{g})$, where the samples of plants dried at $80^{\circ} \mathrm{C}$ for 48 hours and weighed by sensitive balance.

(b) The amount of chlorophyll, which was measured using Chlorophyll Meter SPAD-502 (SPAD units) and the days to $50 \%$ flowering.

(c) Measurements at harvesting: plant height (cm), plant weight $/$ plant $(\mathrm{g})$ and grain yield $/ \mathrm{m}^{2}(\mathrm{~g})$.

Egyptian J. Desert Res., 70, No. 2, 103-119 (2020) 


\section{Experimental Design and Statistical Analysis}

The field experiment was carried out as split-plot in a randomized complete block design (RCBD) arrangement of two factors, the first one was the six locations (three treatments $x$ two years) and the second factor was six genotypes in three replicates.

The means were compared based on the LSD test $(P \leq 0.05)$ as described by Steel et al. (1997). The random model was accepted in order to construct the expected mean squares to identify the genotype, genotype $\mathrm{x}$ location (drought levels treatments during the two growing seasons) and environmental variances according to the formulae of Comstock and Moll (1963), Kumar et al. (1985), Fehr (1987) and Hallauer et al. (2010) as shown in table (1).

Table (1). Expected mean squares of genotypes in cross environments.

\begin{tabular}{cccc}
\hline $\begin{array}{c}\text { Source of } \\
\text { variance }\end{array}$ & d.f & $\begin{array}{c}\text { Mean } \\
\text { square }\end{array}$ & $\begin{array}{c}\text { Expected mean } \\
\text { square }\end{array}$ \\
\hline Replicates & $(\mathrm{r}-1)$ & & \\
Locations (L) & $(1-1)$ & & \\
Error (a) & $\mathrm{e}(\mathrm{r}-1)$ & & \\
Genotypes (G) & $(\mathrm{g}-1)$ & $\mathrm{M} 3$ & $\sigma_{\mathrm{e}}^{2}+\mathrm{r}_{\mathrm{gl}}^{2}+\mathrm{rl} \mathrm{g} \sigma_{\mathrm{g}}^{2}$ \\
$\quad$ G x L & $(\mathrm{g}-1)(1-1)$ & $\mathrm{M} 2$ & $\sigma_{\mathrm{e}}^{2}+\mathrm{r}_{\mathrm{gl}}^{2}$ \\
Error (b) & $\mathrm{L}(\mathrm{r}-1)(\mathrm{g}-1)$ & $\mathrm{M} 1$ & $\sigma_{\mathrm{e}}^{2}$ \\
\hline
\end{tabular}

- Genotypic variance $\left(\sigma_{\mathrm{g}}^{2}\right)=(\mathrm{M} 3-\mathrm{M} 2) / \mathrm{rl}$.

- Interaction Genotype x location $\left(\sigma_{\mathrm{gl}}^{2}\right)=(\mathrm{M} 2-\mathrm{M} 1) / \mathrm{r}$.

- Phenotypic variance $\left(\sigma_{\mathrm{p}}^{2}\right)=(\mathrm{M} 3-\mathrm{M} 2) / \mathrm{rl}+(\mathrm{M} 2-\mathrm{M} 1) / \mathrm{r}+\mathrm{M} 1$.

- Genotypic coefficient of variation $(\mathrm{GCV})=\left[\left(\sigma_{\mathrm{g}}^{2}\right)^{0.5} / \bar{X}\right] * 100$.

- Environment coefficient of variation $(\mathrm{ECV})=\left[\left(\sigma_{\mathrm{e}}^{2}\right)^{0.5} / \bar{X}\right] * 100$.

- Interaction Genotype $\mathrm{x}$ location of variation $(\mathrm{ICV})=\left[\left(\sigma_{\mathrm{gl}}^{2}\right)^{0.5} / \bar{X}\right] * 100$. Where $r$ is the number of experiment replicates, $\mathrm{n}$ is the number of environments, $\bar{X}$ is general mean of each trait.

- Heritability in a broad sense $\left(\mathrm{h}^{2} \mathrm{~b}\right)$ was estimated according to Falconar and Mackay (1996) as follows: $\left(\sigma 2_{\mathrm{g}} / \sigma 2_{\mathrm{p}}\right) * 100$.

- On the other hand, expected genetic advance $(\mathrm{GA})=\mathrm{K} \sigma_{\mathrm{p}}$, where $\mathrm{K}$ is a constant (2.06 for selecting $5 \%$ of the genotypes).

Based on the behavior of tested genotypes under high drought stress (Ys) and normal conditions (Yn), drought tolerance indices were estimated of both fresh weight and grain yield in table (2) as follows:

Egyptian J. Desert Res., 70, No. 2, 103-119 (2020) 
Table (2). Drought tolerance indices based of grain yield $/ \mathrm{m}^{2}$ under stress and non-stress conditions.

\begin{tabular}{ccc}
\hline Parameter & Formula & Reference \\
\hline Stress susceptibility index & $\mathrm{SSI}=1-(\mathrm{Ys} / \mathrm{Yn}) / \mathrm{SI}$ & Fisher and Maurer (1978) \\
(SSI) & where $\mathrm{SI}=1-(\hat{\mathrm{Y} s} / \hat{\mathrm{Y} n})$ & \\
Stress Tolerance Index (STI) & $\mathrm{STI}=(\mathrm{Yn} \times \mathrm{Ys}) /(\hat{\mathrm{Y} n})^{2}$. & Fernández $(1992)$ \\
Harmonic mean (HM) & $\mathrm{HM}=2(\mathrm{Yn} \times \mathrm{Ys}) /(\mathrm{Yn}+\mathrm{Ys})$ & Kristin et al. $(1997)$ \\
Mean Productivity (MP) & $\mathrm{MP}=(\mathrm{Yn}+\mathrm{Ys}) / 2$ & Rosielle and Hamblin $(1981)$ \\
Yield injury \% (YI) & $\mathrm{YI}=[(\mathrm{Yn}-\mathrm{Ys}) / \mathrm{Yn}] \times 100$ & Blum $(1983)$ \\
Superiority measure (SM) & $\mathrm{SM}=\mathrm{Ys} / \mathrm{Yn}$ & Lin and Binns $(1988)$ \\
Relative performance (RP) & $\mathrm{RP}=(\mathrm{Ys} / \mathrm{Yn}) / \mathrm{R}$ & Abo-Elwafa and Bakheit \\
& where $\mathrm{R}=(\hat{\mathrm{Y} s} / \hat{\mathrm{Y} n})$ & $(1999)$ \\
\hline
\end{tabular}

Where; $\mathrm{Yn}=$ grain yield without non-stress; $\mathrm{Ys}=$ grain yield with high stress level; $\hat{Y}_{\mathrm{S}}=$ the means of all genotypes under drought stress; $\hat{Y} n=$ the means of all genotypes under non-stress conditions.

According to the biplot graphing, a data analysis and management system were implemented using version 7 of GGE biplot technique to distribute the genotypes tested during the studied environments based on the grain yield (Yan and Kang, 2003).

\section{RESULTS}

\section{Performance of Tested Genotypes under Different Conditions}

Mean square based on $\mathrm{F}$ test of variance sources represented by locations (three drought levels $\mathrm{x}$ two seasons), genotype, location $\mathrm{x}$ genotype interaction indicated that there are significant differences for all studied characteristics as shown in table (3).

The results in table (4) show that the use of increased levels of water stress caused negative effects on all studied characters with a clear variance among tested genotypes under used water stress levels (Fig. 1). In this context, the results of the phenotypic performance of Shandawil variety indicate its superiority under conditions of non-water stress (control), especially for grain yield during the growing two seasons (188.93 and $184.33 \mathrm{~g} / \mathrm{m}^{2}$, respectively), while Line 3 (SP 4487-3) showed a clear superiority under severe water stress conditions (treatment 3 ) for most characteristics during growing two seasons, especially grain yield ( 167.67 and $171.40 \mathrm{~g} / \mathrm{m}^{2}$, respectively).

In general, the results in table (4) show the superior performance of the Shandaweil variety under normal conditions (non-stress), while genotype 3 showed a marked superiority under high drought stress conditions compared to other genotypes (Fig. 2). In the same context, the results showed that under moderate water deficiency stress conditions, both genotypes 3, 5 and Shandawil variety were distinguished.

Egyptian J. Desert Res., 70, No. 2, 103-119 (2020) 
Table (3). Mean squares for the studied characters of genotypes under treatments.

\begin{tabular}{|c|c|c|c|c|c|c|c|}
\hline S.O.V & d.f & $\begin{array}{c}\text { Fresh } \\
\text { weight }\end{array}$ & $\begin{array}{c}\text { Dry } \\
\text { weight }\end{array}$ & $\begin{array}{c}\text { Chlorophyll } \\
\text { content }\end{array}$ & $\begin{array}{c}\text { Days to } 50 \% \\
\text { flowering }\end{array}$ & $\begin{array}{c}\text { Plant } \\
\text { height }\end{array}$ & $\begin{array}{l}\text { Grain } \\
\text { yield }\end{array}$ \\
\hline Replicates & 2 & & & & & & \\
\hline Locations (L) & 5 & $3792.01 * *$ & $390.46^{* *}$ & $355.08^{* *}$ & $397.62 * *$ & $4045.32 * *$ & $582.81 * *$ \\
\hline Error (a) & 10 & 14.101 & 8.327 & 2.102 & 1.761 & 15.748 & 0.676 \\
\hline Genotypes (G) & 5 & $5368.58 * *$ & $734.56^{* *}$ & $11.33^{* *}$ & $452.57 * *$ & $11100.03 * *$ & $1378.29 * *$ \\
\hline $\mathrm{G} \times \mathrm{L}$ & 25 & $38.19^{* *}$ & $39.48^{* *}$ & $26.63^{* *}$ & $3.706^{* *}$ & $611.67 * *$ & $79.81 * *$ \\
\hline Error (b) & 60 & 9.50 & 3.92 & 3.24 & 2.20 & 6.52 & 1.46 \\
\hline
\end{tabular}

Table (4). Mean performance of tested genotypes under three treatments during the two growing seasons.

\begin{tabular}{|c|c|c|c|c|c|c|c|c|}
\hline Season & Treatment & Genotype & $\begin{array}{c}\text { Fresh } \\
\text { Weight } \\
\text { (g) }\end{array}$ & $\begin{array}{c}\text { Dry } \\
\text { weight } \\
\text { (g) }\end{array}$ & $\begin{array}{l}\text { Chlorophyll } \\
\text { Content } \\
\text { (SPAD) }\end{array}$ & $\begin{array}{c}\text { Days to } \\
50 \% \\
\text { flowering }\end{array}$ & $\begin{array}{l}\text { Plant } \\
\text { height } \\
(\mathrm{cm})\end{array}$ & $\begin{array}{c}\text { Grain } \\
\text { yield } / \mathrm{m}^{2} \\
(\mathrm{~g})\end{array}$ \\
\hline \multirow{21}{*}{$1^{\text {st }}$} & \multirow{7}{*}{$\mathrm{T} 1$} & Dorado & 130.16 & 38.96 & 39.63 & 86.00 & 85.00 & 125.90 \\
\hline & & Shandawil & 166.83 & 54.87 & 38.23 & 80.33 & 110.00 & 188.93 \\
\hline & & Hybrid & 123.74 & 37.02 & 38.23 & 77.00 & 90.00 & \\
\hline & & 306 & & & & & & 166.61 \\
\hline & & Line 1 & 126.84 & 37.91 & 35.70 & 91.00 & 150.00 & 114.14 \\
\hline & & Line 2 & 142.69 & 50.97 & 36.47 & 85.33 & 140.00 & 166.62 \\
\hline & & Line 3 & 150.63 & 52.42 & 35.43 & 84.33 & 115.00 & 182.99 \\
\hline & \multirow{7}{*}{$\mathrm{T} 2$} & Dorado & 119.44 & 33.96 & 35.07 & 85.00 & 65.00 & 103.99 \\
\hline & & Shandawil & 156.42 & 53.15 & 35.30 & 78.00 & 100.00 & 120.35 \\
\hline & & Hybrid & 112.01 & 36.14 & 36.23 & 74.33 & 85.00 & \\
\hline & & 306 & & & & & & 99.46 \\
\hline & & Line 1 & 111.81 & 36.96 & 38.40 & 88.33 & 140.33 & 115.84 \\
\hline & & Line 2 & 132.84 & 40.12 & 36.30 & 82.33 & 105.00 & 156.91 \\
\hline & & Line 3 & 144.10 & 50.46 & 39.37 & 80.33 & 115.00 & 188.19 \\
\hline & \multirow{7}{*}{ T3 } & Dorado & 98.48 & 29.14 & 35.67 & 82.33 & 65.33 & 89.07 \\
\hline & & Shandawil & 136.25 & 36.17 & 40.37 & 74.33 & 95.00 & 114.80 \\
\hline & & Hybrid & 95.75 & 29.09 & 39.10 & 70.00 & 75.00 & \\
\hline & & 306 & & & & & & 93.57 \\
\hline & & Line 1 & 96.53 & 32.96 & 38.23 & 83.00 & 110.00 & 110.25 \\
\hline & & Line 2 & 102.76 & 35.13 & 42.50 & 79.33 & 100.00 & 124.55 \\
\hline & & Line 3 & 125.22 & 39.56 & 37.60 & 77.00 & 90.00 & 167.67 \\
\hline
\end{tabular}

Egyptian J. Desert Res., 70, No. 2, 103-119 (2020) 
Table (4). Cont.

\begin{tabular}{|c|c|c|c|c|c|c|c|c|}
\hline \multirow{21}{*}{$2^{\text {nd }}$} & \multirow{7}{*}{$\mathrm{T} 1$} & Dorado & 128.94 & 36.19 & 45.60 & 79.67 & 88.67 & 122.44 \\
\hline & & Shandawil & 165.12 & 46.30 & 46.97 & 75.33 & 123.67 & 184.33 \\
\hline & & Hybrid & 126.75 & 35.35 & 47.40 & 68.67 & 103.00 & \\
\hline & & 306 & & & & & & 160.68 \\
\hline & & Line 1 & 128.05 & 33.45 & 40.97 & 6.00 & 143.67 & 122.47 \\
\hline & & Line 2 & 147.81 & 49.24 & 39.63 & 80.33 & 198.33 & 156.95 \\
\hline & & Line 3 & 165.56 & 42.29 & 42.37 & 78.33 & 124.67 & 173.93 \\
\hline & \multirow{7}{*}{$\mathrm{T} 2$} & Dorado & 119.94 & 38.41 & 43.10 & 77.00 & 83.67 & 104.58 \\
\hline & & Shandawil & 166.00 & 43.03 & 41.60 & 72.00 & 109.00 & 131.63 \\
\hline & & Hybrid & 123.68 & 34.31 & 43.03 & 66.33 & 97.00 & \\
\hline & & 306 & & & & & & 114.56 \\
\hline & & Line 1 & 118.41 & 35.46 & 47.07 & 82.33 & 173.67 & 109.20 \\
\hline & & Line 2 & 135.95 & 48.82 & 44.53 & 77.33 & 133.00 & 161.62 \\
\hline & & Line 3 & 145.17 & 55.55 & 47.30 & 72.33 & 128.00 & 171.45 \\
\hline & \multirow{7}{*}{$\mathrm{T} 3$} & Dorado & 102.18 & 29.24 & 49.53 & 71.33 & 72.00 & 90.31 \\
\hline & & Shandawil & 135.08 & 39.98 & 49.43 & 67.33 & 103.00 & 112.65 \\
\hline & & Hybrid & 96.48 & 29.14 & 48.63 & 65.00 & 88.67 & \\
\hline & & 306 & & & & & & 95.02 \\
\hline & & Line 1 & 99.33 & 30.09 & 53.43 & 78.00 & 146.67 & 109.53 \\
\hline & & Line 2 & 109.64 & 32.20 & 44.43 & 72.33 & 101.67 & 136.99 \\
\hline & & Line 3 & 129.38 & 46.51 & 40.43 & 71.00 & 97.67 & 171.40 \\
\hline & LSD & & 5.04 & 3.24 & 2.94 & 2.42 & 4.17 & 5.91 \\
\hline
\end{tabular}

\section{Variance Components, Heritability in A broad Sense and Genetic Advance}

Table (5) shows the data related to the variance components and its coefficients, heritability in broad sense and genotype advance ratios of tested characters. The results of the variance components of most studied traits showed that the major contribution in phenotypic performance is due to the genetic variation of the tested genotypes, especially in plant height (95.98\%) traits followed by both dry and fresh weight (68.21 and 57.15\%, respectively). On the other hand, the results show that the variation in the chlorophyll content trait is due more to the variation resulting from the genotype $\mathrm{x}$ location interaction (12.44\%) compared with genotypic coefficient of variation $(8.18 \%)$. The results showed an increase in heritability (\%) in broad sense of all studied characteristics, except chlorophyll content, where the values range from $27.82 \%$ of chlorophyll content and $99.12 \%$ of fresh weight. With regard to the genetic advances, the results showed a clear discrepancy among the studied traits, as the characteristics of the plant height, fresh weight, and grain 
yield of the plant recorded the highest genetic advance, while the chlorophyll content recorded the lowest genetic advance of the plants (13.25\%).

Table (5). Variance components, heritability in a broad sense and genetic advance of all tested characters.

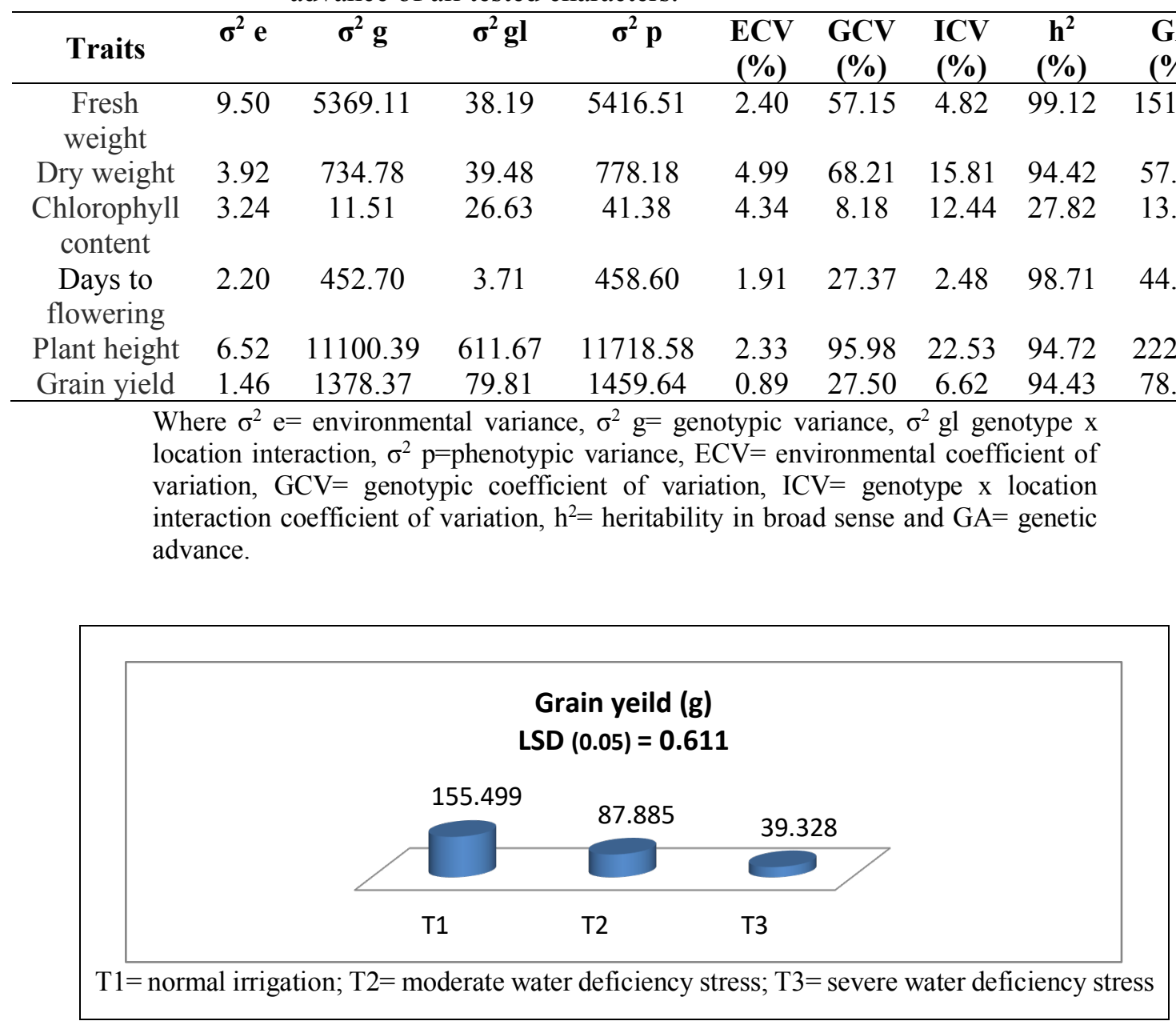

Fig. (1). The comparison between irrigation treatments based on grain yield $/ \mathrm{m}^{2}$ across the two seasons.

Egyptian J. Desert Res., 70, No. 2, 103-119 (2020) 


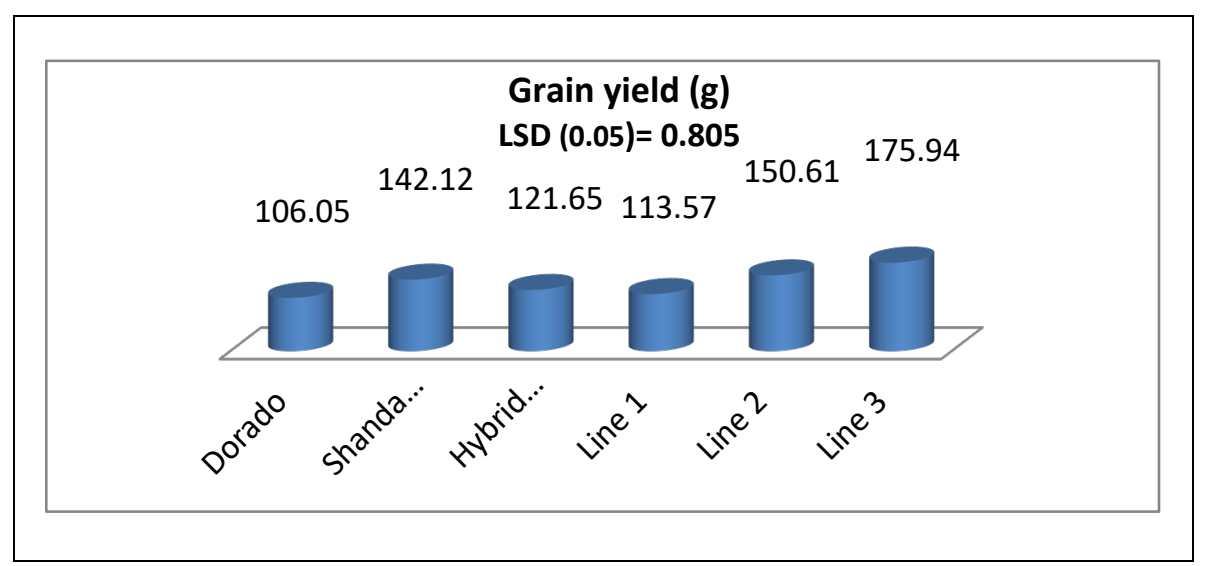

Fig. (2). The comparison between tested genotypes based on grain yield $/ \mathrm{m}^{2}$ across the two seasons.

\section{Drought Tolerance Indices and Genotype X Environment (GE) Using GGE biplot}

The data in table (6) represent stress tolerance indices for performance evaluation of some sorghum genotypes under drought water stress condition, grain yield/plant of genotypes under both non-stress (normal) and high stress level were measured for estimating drought tolerance indices. In general, the mean values of the yield for the group of genotypes show that the Shandawil variety exceeded the rest of the genotypes under normal condition, while under severe drought stress conditions; the line 3 recorded the highest values during the two growing seasons (167.67 and 171.40, respectively). Based on the results of the stress susceptibility index values (Table 6) during the two growing seasons, the genotypes were divided into two groups, the first group is less than 1 and represented the most tolerant ones (Line 3, Line 1 and Line 2 ), respectively, while the second group is greater than 1 and represented the genotypes that are less tolerant to drought (Dorado, Shandawil and Hybrid 306 , respectively). In the same context, stress tolerance index (STI) results during the growing seasons confirm the superiority of line 3, followed by both Shandawil and Line 2. Also, the results of the harmonic mean (HM) and mean productivity (MP) indices were consistent with the same results of stress tolerance index completely with regard to the superiority of line 3, followed by both Shandawil and Line 2 during the growing seasons.

Accordingly yield injury (YI), Hybrid 306 cultivar recorded the highest deficiency in grain yield (43.84 and $40.86 \%$ ) followed by Shandawil cultivar (39.24 and $38.89 \%$ during the two growing seasons, respectively), while Line 3 recorded the lowest deficiency in grain yield $(8.37$ and $1.46 \%$, respectively), followed by Line 1 (3.41 and $10.57 \%$, respectively) during the two seasons. With regard to superiority measure (SM) and relative performance (RP), each of Line 1 and Line 3 genotypes have scored the 
highest mean compared to other genotypes, while Hybrid 306 cultivar has scored the lowest mean values of SM (0.56 and 0.59$)$ and $\mathrm{Rp}(0.76$ and 0.76$)$ during two growing seasons, respectively, as shown in table (6).

On the other hand, it is possible to rely on the graphic (GGE biplot) form to distribute the genotypes during the different environments under study, which is shown in Fig. (3). It is noted that Line 3 followed by Line 2 are distinguished in their grain yield in environments 3,6 and 2, which are the most drought environments, while the Dorado variety is distinguished under normal environments, which are presented in E1 and E4.

Table (6). Tolerance indices of tested quinoa genotypes of grain yield $/ \mathrm{m}^{2}(\mathrm{~g})$ under drought stress (Ys) and non- stress (Yn) condition during the growing two seasons.

\begin{tabular}{|c|c|c|c|c|c|c|c|c|c|c|}
\hline Season & Genotype & Yn & Ys & SSI & STI & HM & MP & $\begin{array}{c}\text { YI } \\
(\%)\end{array}$ & SM & $\mathbf{R P}$ \\
\hline \multirow{6}{*}{$1^{\text {st }}$} & Dorado & 125.90 & 89.07 & 1.127 & 0.452 & 104.33 & 107.49 & 29.25 & 0.71 & 0.96 \\
\hline & Shandawil & 188.93 & 114.8 & 1.512 & 0.874 & 142.82 & 151.87 & 39.24 & 0.61 & 0.82 \\
\hline & Hybrid 306 & 166.61 & 93.57 & 1.689 & 0.628 & 119.84 & 130.09 & 43.84 & 0.56 & 0.76 \\
\hline & Line 1 & 114.14 & 110.25 & 0.131 & 0.507 & 112.16 & 112.20 & 3.41 & 0.97 & 1.30 \\
\hline & Line 2 & 166.62 & 124.55 & 0.973 & 0.836 & 142.55 & 145.59 & 25.25 & 0.75 & 1.01 \\
\hline & Line 3 & 182.99 & 167.67 & 0.323 & 1.236 & 175.00 & 175.33 & 8.37 & 0.92 & 1.24 \\
\hline & Mean & $\mathbf{1 5 7 . 5 3}$ & 116.65 & 1.000 & 0.740 & 134.04 & 137.09 & 25.95 & 0.74 & 1.00 \\
\hline \multirow{7}{*}{$2^{\text {nd }}$} & Dorado & 122.44 & 90.31 & 1.179 & 0.469 & 103.95 & 106.38 & 26.24 & 0.74 & 0.95 \\
\hline & Shandawil & 184.33 & 112.65 & 1.747 & 0.882 & 139.84 & 148.49 & 38.89 & 0.61 & 0.79 \\
\hline & Hybrid 306 & 160.68 & 95.02 & 1.836 & 0.649 & 119.42 & 127.85 & 40.86 & 0.59 & 0.76 \\
\hline & Line 1 & 122.47 & 109.53 & 0.475 & 0.570 & 115.64 & 116.00 & 10.57 & 0.89 & 1.15 \\
\hline & Line 2 & 156.95 & 136.99 & 0.572 & 0.913 & 146.29 & 146.97 & 12.72 & 0.87 & 1.12 \\
\hline & Line 3 & 173.93 & 171.40 & 0.065 & 1.266 & 172.66 & 172.67 & 1.46 & 0.98 & 1.27 \\
\hline & Mean & 153.47 & 119.32 & 1.000 & 0.777 & 134.25 & 136.39 & 22.25 & 0.78 & 1.00 \\
\hline
\end{tabular}

Where: $\mathrm{Yn}=$ grain yield without non-stress; $\mathrm{Ys}_{\mathrm{s}}$ grain yield with high stress level; $\mathrm{SSI}=$ stress susceptibility index; $\mathrm{STI}=$ stress tolerance index; $\mathrm{HM}=$ harmonic mean; $\mathrm{MP}=$ mean productivity; $\mathrm{YI}=$ yield injury; $\mathrm{SM}=$ superiority measure; $\mathrm{RP}=$ relative performance.

Egyptian J. Desert Res., 70, No. 2, 103-119 (2020) 


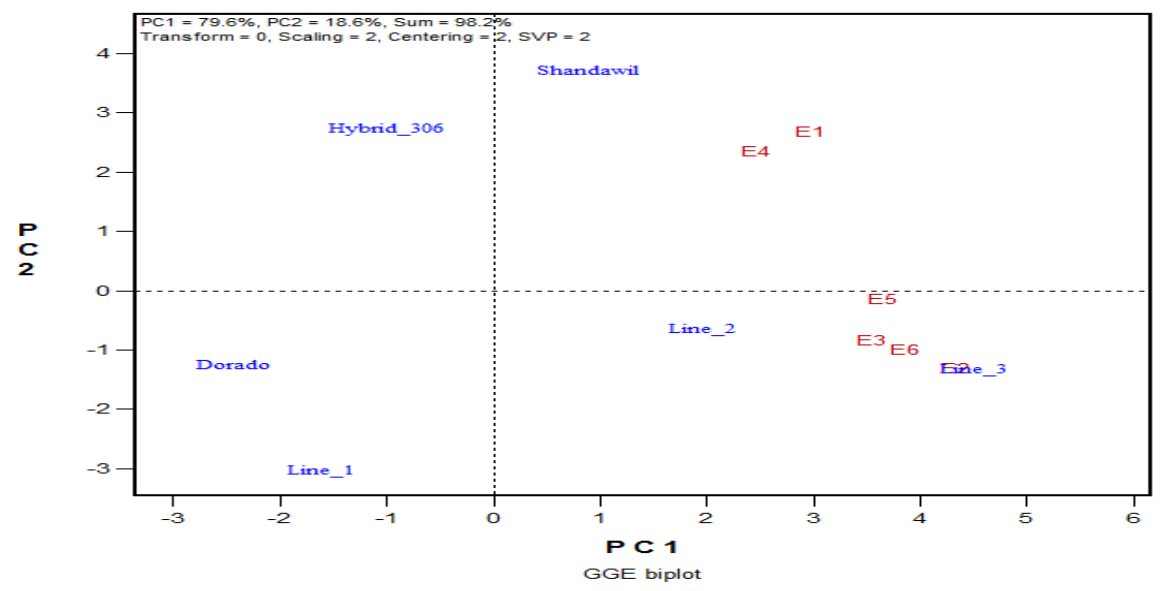

Fig. (3). Deviations of 6 tested genotypes at six environments (E1 to E6) based on the mean of grain yield.

\section{DISCUSSION}

Variance analysis of tested characters indicated that the mean squares of locations (water deficit levels across the two growing seasons) were significant and highly significant for all characters. Also, most of characters showed high significance of mean squares due to genotypes and interaction between genotypes and locations, implying that the treatments and genotypes tested across the two seasons were highly diverse. It is worth mentioning in this study that the values of the experimental error or the environmental variance of the studied characteristics are low, while studies confirm that in the case of high values of the experimental error, the sample size is not appropriate due to the number of treatments, season locations and it is an indication of lack of credibility in the results (Zaveri et al., 1989 and Bello et al., 2007), and this is not found in this study.

\section{Variance Components, Heritability in A broad Sense and Genetic Advance}

The discussion of Genetic variability is the primary rule required for breeders to improve the quantity and quality of yield through suitable way of selection based on materials variability.

According to the data in table (5), phenotypic variance $\left(\sigma^{2} \mathrm{ph}\right)$ was greater than genotypic variance $\left(\sigma^{2} \mathrm{~g}\right)$ for all tested characters and this means that the performance of these studied characters is related to the environmental effect. It is worth discussing in this regard the importance of dividing the variance into its components that confirm the importance of the differences

Egyptian J. Desert Res., 70, No. 2, 103-119 (2020) 
that are to the most part due to the genotypes, followed by the interaction between the genotypes and the surrounding environmental conditions, which confirms the diversity of these genotypes and their importance in any breeding program under the conditions of abiotic environmental stresses. For example, the data in table (5) confirm the high percentage of the genetic variation coefficient (GCV), followed by the genotype $\mathrm{x}$ location (ICV) for all studied traits, except for the chlorophyll content trait. These results are in harmony with that of cultivated sorghum by Bello et al. (2007) and also Basu et al. (1981) and Abu-Gasim et al. (1985), who found similar results in sorghum crop.

Sardana et al. (2007) indicated that high heritability may not be sufficient genetic variability existed in the genotypes. Although, in this study, high heritability values were recorded coupled with the highest genetic advance values and inversely, where the highest values of genetic advance of fresh weight and plant height traits were recorded also with high heritability coefficient, and also the lowest values for the heritability coefficient of chlorophyll content trait recorded also with genetic advance under non-stress and drought condition. The previous results indicated that it is possible to select for the high traits in the heritability values and the genetic improvement of yield, and this is consistent with Ahmed and Khaliq (2007) and Songsri et al. (2008), who confirmed that better heritability values recorded point to the possibility of improvement in this parameter. Similar results of both heritability and high genetic advance for yield and its components were evidenced in sorghum by Arunkumar et al. (2004). On the other hand, the reason for the low heritability of chlorophyll content is due to the clear impact of environmental conditions on the tested genotypes.

\section{Resistance Indices and Genotype $X$ Environment (GE) Using GGE biplot}

In the context of the limited water and the increasing conflict over it, so it became necessary to focus on the selection of genotypes, especially for crops grown to face these harsh environmental changes. The results of this study can separate the tested sorghum genotypes to tolerant and sensitive under non-stress and drought stress conditions based on grain yield and its components. Regarding the results of this study, they are consistent or relatively different with the results of other studies, based on the preference of the indices used among them. For example, the selection based on a stress susceptibility index (SSI) is considerd reliable index for selecting high grain yielding genotypes for improving drought resistance in crops (Ramirez and Kelly, 1998 and Guttieri et al., 2001 and Badran and Moustafa, 2015). While, Golabadi et al. (2006), Pourdad (2008), Talibi et al. (2009) and Majidi et al. (2011) mentioned that the best criterion for determining genotypes that are more resistant to moisture stress conditions compared to non-stress field

Egyptian J. Desert Res., 70, No. 2, 103-119 (2020) 
environments (normal conditions) with a higher yield is the Stress Tolerance Index (STI), Geometric Average Productivity (GMP) and Means Productivity (MP). So, it could be possible to take advantage of a variety of indices to make categorization of a tested genotypes groups under both drought stress and normal conditions in the form of groups as follows: (1) the first group, the genotypes that give a better yield under non-stress conditions, (2) the second group, the genotypes that give a higher yield under the environmental stress conditions, (3) the third group, the genotypes that is distinguished in the crop under water stress compared to normal conditions, (4) the fourth group that is medium tolerated under water stress compared to normal conditions, (5) the fifth group, which gave the lowest grain yield under water stress compared to the normal conditions. These previous findings are in harmony with Fernández (1992) and Badran (2015), who reported that, genotypes are classified into four groups according to their performance under non-stress and water stress conditions.

Recently, GGE biplot diagrams can be relied upon to compare genotypes based on average grain yield during different environments. To determine which genotypes are particularly distinct under specific environmental conditions and may therefore be filtered for selection and crossbreeding in a breeding program under specific conditions ( $Y$ an and Rajcan, 2002 and Yan and Kang, 2003).

\section{CONCLUSION}

In conclusion, this study indicates the importance of assessing the variability components of sorghum genotypes based on its grain yield under various environments. Regard to the high heritability coefficient and the expected high genetic advance shown by various traits, especially the grain yield, it can be concluded that the specific genetic variance of the phenotypic expression of these traits plays a fundamental role in characterizing these genotypes. Also, resistance indices for harsh environmental conditions compared to optimal conditions, are useful in classifying these genotypes into groups that are associated with specific conditions.

\section{ACKNOWLEDGEMENT}

The author expresses his gratitude and appreciation to each of the scientific institutions that provided these genotypes and the farmers working in Beni-Suef for assistance during fieldwork.

Egyptian J. Desert Res., 70, No. 2, 103-119 (2020) 


\section{REFERENCES}

Abo-Elwafa A. and B.R. Bakheit (1999). Performance, correlation and path coefficient analysis in faba bean. Assiut J. Agric. Sci, 30: 77-91.

Abu-Gasim, E.H., and A.E. Kambal (1985). Variability and interrelationship among characters in indigenous grain sorghum of the Sudan, Crop Science, 11: 308-309.

Ahmad, S.Q., S. Khan, M. Ghaffar and F. Ahmad (2011). Genetic diversity analysis for yield and other parameters in maize (Zea mays L.) genotypes. Asian Journal of Agricultural Sciences, 3 (5): 385-388.

Ahmed, N.C.M. and I.M.M. Khaliq (2007). The inheritance of yield and yield components of five wheat hybrid populations under drought conditions. Indonesian J. Agric. Sci., 8 (2): 53-59.

Arunkumar, B., B.D. Biradar and P.M. Salimath (2004). Genetic variability and character association studies in rabi sorghum. Karnataka Journal of Agricultural Science, 17: 471-475.

Badran, A.E. (2015). Comparative analysis of some garlic varieties under drought stress conditions. Journal of Agricultural Science, 7 (10): 271-280.

Badran, A.E. and E.S.A. Moustafa (2015). Genetic parameters of some wheat (Triticum aestivum L.) genotypes using factorial mating design. Journal of Agricultural Science, 7 (1): 101-105.

Basu, A.K. (1981). Variability and heritability estimate from inter-season sorghum cross, Indian Journal of Agricultural Sciences, 41: 116-117.

Bello, D., A.M. Kadams, S.Y. Simon and D.S. Mashi (2007). Studies on genetic variability in cultivated sorghum (Sorghum bicolor L. Moench) cultivars of Adamawa State Nigeria. American-Eurasian Journal of Agricultural Environmental Science, 2 (3): 297-302.

Blum, A., H. Poyarkova, G. Golan and J. Mayer (1983). Chemical desiccation of wheat plants as a simulator of postanthesis stress. I. Effects on translocation and kernel growth. Field Crops Research, 6: 51-58.

Comstock, R.E. and R.H. Moll (1963). Genotype-environment Interactions. In: "Statistical Genetics and Plant Breeding". NAS-NRC. Publ. 982, p.164-196.

Falconar, D.S and T.F.C. Mackay (1996). In: "Introduction to Quantitative Genetics". Chapman and Hall, London, UK.

FAOSTAT, Statistical Yearbook (2013). World Food and Agriculture, Organization UN, Rome, Italy. Available online: http://faostat.fao.org/site/291/default.aspx.

Fernández, G.C.J. (1992). Effective selection criteria for assessing plant stress tolerance. In: Proceedings of the International Symposium on Adaptation of Vegetables and other Food Crops in Temperature and Water Stress, Chapter 25, Taiwan, p. 257-270.

Egyptian J. Desert Res., 70, No. 2, 103-119 (2020) 
Fehr, W.R. (1987). Heritability. In: "Principles of Cultivar Development Theory and Technique". Fehr, W.R. (Ed.). McMillan Pub. Co., New York, p. 95-105.

Fisher, R.A. and R. Maurer (1978). Drought resistance in spring wheat cultivars. 1. Grain yield response. Aust. J. Agric. Res., 29: 897-912.

Golabadi, M., A. Arzani and S.A.M. Maibody (2006). Assessment of drought tolerance in segregating populations in durum wheat. Afr. J. Agric. Res., 5: 162-171.

Guttieri, M.J., J.C. Stark., K. Brien and E. Souza (2001). Relative sensitivity of spring wheat grain yield and quality parameters to moisture deficit. Crop Sci., 41: 327-335.

Hallauer, A.R., M.J. Carena and J.B. Miranda Filho (2010). Quantitative genetics in maize breeding. $3^{\text {rd }}$ Ed. Spring, New York, USA, 500 pp.

Khurmi, R. S. (1984). A text book of hydraulics, fluid mechanics and hydraulic machines. Chand S. and Company Ltd., Ram Nagar, New Delhi.

Kumar, A., S.C. Misra., Y.P. Singh and B.P.S. Singh (1985). Variability and correlation studies in triticale. J. Maharashtra Agric. Univ., 10: 273275.

Kristin, A.S., R.R. Senra., F.I. Perez., B.C. Enriquez., J.A.A. Gallegos., P.R. Vallego., N. Wassimi and J.D. Kelley (1997). Improving common bean performance under drought stress. Crop Sci., 37: 43-50.

Lin, C.S. and M.R. Binns (1988). A superiority measure of cultivar performance for cultivar x location data. Can. J. Plant Sci., 68: 193198.

Majidi, M., V. Tavakoli., A. Mirlohi and M.R. Sabzalian (2011). Wild safflower species (Carthamus oxyacanthus Bieb.): A possible source of drought tolerance for arid environments. Aust. J. Crop Sci., 5 (8): 1055-1063.

Maman, N., S.C. Mason, D.J. Lyon and P. Dhungana (2004). Yield components of pearl millet and grain sorghum across environments in the central Great Plains, Crop Science, 44 (6): 2138-2145.

Mindaye, T.T., E.S, Mace., I.D. Godwin and D.R. Jordan (2016). Heterosis in locally adapted sorghum genotypes and potential of hybrids for increased productivity in contrasting environments in Ethiopia. The Crop Journal 4: 479-489.

Mitra, J. (2001). Genetics and genetic improvement of drought resistance in crop plants. Curr. Sci., 80: 758-762.

Pourdad, S.S. (2008). Study of drought resistance indices in spring safflower. Acta Agron. Hung., 56: 203-212.

Rosielle, A.A. and J. Hamblin (1981). Theoretical aspects of selection for yield in stress and non-stress environments. Crop Sci., 21: 943-946.

Sami, R.A., M.Y. Yeye., M.F. Ishiyaku and I. S. Usman (2013). Heritability studies in some sweet sorghum (Sorghum bicolor. L. Moench)

Egyptian J. Desert Res., 70, No. 2, 103-119 (2020) 
genotypes. Journal of Biology Agriculture and Healthcare, 3 (17): 49-51.

Sardana, S., R. Mahjan, N. Gautam and B. Ram (2007). Genetic variability in pea (Pisum sativum L.) germplasm for utilization. SABRAO J. Breed. Genet., 39 (10): 31-41.

Shirani, Rad A.H. and A. Abbasian (2011). Evaluation of drought tolerance in winter rapeseed cultivars based on tolerance and sensitivity indices. Žemdirbystė Agricult., 98: 41-48.

Sio-Se Mardeh, A., A. Ahmadi., K. Poustini and V. Mohammadi (2006). Evaluation of drought resistance indices under various environmental conditions. Field Crops Res., 98: 222-229.

Songsri, P., S. Joglloy, T. Kesmala, N. Vorasoot, C.P.A. Akkasaeng and C. Holbrook (2008). Heritability of drought resistance traits and correlation of drought resistance and agronomic traits in peanut. Crop Sci., 48: 2245-2253.

Steel, R.G.D., J.A. Torrie and D.A. Deckey (1997). In: "Principles and Procedures of Statistics: A Biometrical Approach". $3^{\text {rd }}$ Ed., Mc Graw Hill Book INC, New York.

Talibi, R., F. Fayaz and A.M. Naji (2009). Effective selection criteria for assessing drought stress tolerance in durum wheat (Triticum durum Desf.). General and Applied Plant Physiology, 35: 64-74.

Ramirez, P., and J.D. Kelly (1998). Traits related to drought resistance in common bean. Euphytica, 99: 127-136.

Verma, R., R. Kumarand and D. Nath (2018). Drought resistance mechanism and adaptation to water stress in sorghum [Sorghum bicolor (L.) Moench]. Int. J. Bio-res. Str. Man., 91: 167-172.

Yan, W. and I.R. Rajcan (2002). Biplot analysis of test sites and trait relations of soybean in Ontario. Can. J. Plant Sci., 42: 11-20.

Yan, W. and M.S. Kang (2003). In: "GGE-biplot Analysis: A graphical Tool for Breeders". Genet and Agronomists, CRD Press, Boca Raton.

Zaveri, P.P., P.S. Phul and B.S. Dillon (1989). Observed and predicted genetic gains from single and multi-trait selections using three mating designs in pearl millet. Plant Breeding Abstract, 60: 127-132.

Egyptian J. Desert Res., 70, No. 2, 103-119 (2020) 
المدلولات الوراثية لبعض التراكيب الوراثية للارة الرفيعة تحت إجهاد نقص المياه

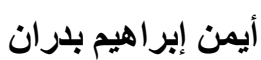

قشم الأصول الور اثية، مركز بحوث الصحر اء، القاهرة، مصر

الذرة الرفيعة من المحاصيل ذات قدرة تأقلمية كبيرة للتكيف مع نقص المياه من خلال

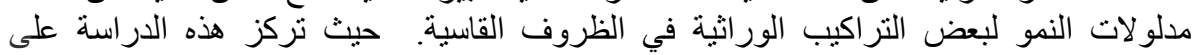

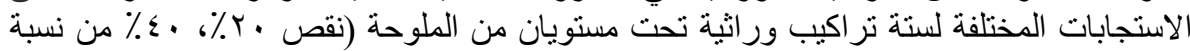

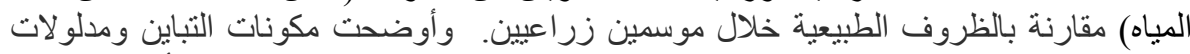

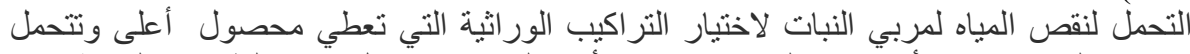

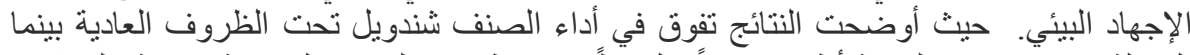

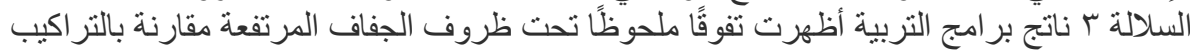

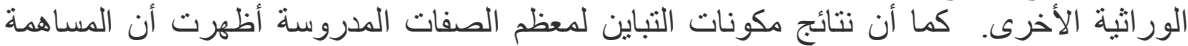

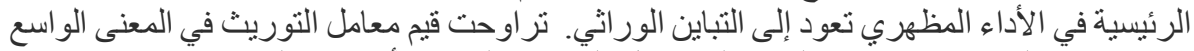

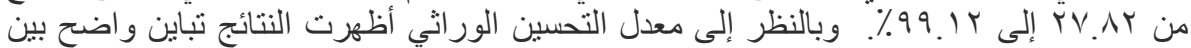

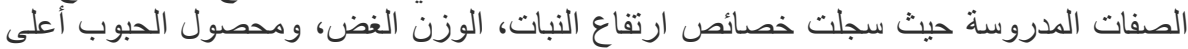
معدل تحسين وراني، بينما سجل محتوى الكلوروفيل أدنى معدل تحسين ور اتثي للنباتات.

Egyptian J. Desert Res., 70, No. 2, 103-119 (2020) 